\title{
NIÑOS, NIÑAS Y ADOLESCENTES SOLICITANTES DE ASILO EN MÉXICO: UNA GRÍTICA A LOS DEFEGTOS DEL PROCEDIMIENTO PARA EL RECONOCIMIENTO DE LA CONDICIÓN DE REFUGIADO*
}

\section{CHILD AND ADOLESCENT ASYLUM SEEKERS IN MEXICO: A CRITIQUE OF THE DEFECTS SURROUNDING THE PROCEDURE FOR RECOGNIZING REFUGEE STATUS}

\author{
Elisa ORTEGA VELÁZQUEZ**
}

\begin{abstract}
El estado de excepción se presenta como la forma legal de aquello que no puede tener forma legal... el orden jurídico parece estar siempre al mismo tiempo fuera y dentro de sí mismo, a la vez vida y norma, hecho y derecho.
\end{abstract}

\section{Giorgio AGAMBEN****}

RESUMEN: Este artículo tiene dos objetivos. De un lado, sistematizar y, de este modo, hacer visible el procedimiento legal al que tienen que enfrentarse los niños, las niñas y los adolescentes (NNA) que deciden buscar asilo en México, dada la opacidad y las dificultades que son inherentes a dicho procedimiento. Y, de otro lado, identificar y analizar los obstáculos más notorios que la forma jurídica específica de este procedimiento crea en su práctica cotidiana, con el
ABSTRACT: This article has two objectives. On the one hand, to systematize and, in this way, highlight the legal procedure that children and adolescents (CAs) have to face when they decide to seek asylum in Mexico, given the opacity and the difficulties that are inherent in said process. And, on the other hand, identify and analyze the most obvious obstacles that the specific legal form of this procedure creates in its daily practice so as to illuminate, from a critical perspective, the actual situation of the right of children/(CAs) to seek and receive asylum in Mexico.

* Artículo recibido el 2 de septiembre de 2017 y aceptado para su publicación el 26 de octubre de 2017.

** ORCID: 0000-0001-7013-0693. Instituto de Investigaciones Jurídicas de la UNAM.

*** Agamben, Giorgio, Estado de excepción. Homo sacer II, I, trad. de Flavia Costa e Ivana Costa, Buenos Aires, 2004, pp. 14 y 24.

Boletín Mexicano de Derecho Comparado, nueva serie, año XLX, núm. 152, mayo-agosto de 2018, pp. 707-739.

Esta obra está bajo una Licencia Creative Commons Atribución-NoComercial-SinDerivar 4.0 Internacional, IIJ-UNAM. 
fin de iluminar, desde una perspectiva crítica, la situación real del derecho de los NNA de buscar y recibir asilo en México. Para tales efectos, primero, se estudiará el procedimiento que debe seguirse para buscar y recibir asilo en México, y, segundo, se examinarán los obstáculos prácticos y jurídicos a los que se enfrentan los niños, las niñas y los adolescentes que inician este tortuoso procedimiento.

Palabras clave: asilo, niños, niñas y adolescentes, México, debido proceso, derechos humanos.
To this end, first, this article studies the procedure that must be followed to seek and receive asylum in Mexico; second, it examines the practical and legal obstacles faced by children and adolescents who initiate this tortuous procedure.

Keyzerds: Asylum, Children, Mexico, Due Process, Human Rights.

Sumario: I. Aproximación. II. El derecho de buscar y recibir asilo en México. III. ¿Quién es refugiado en México? IV. Procedimiento para que los $\mathcal{N N A}$ soliciten asilo en México. V. Determinación de la condición de refugiado por parte de la Comar. VI. Obstáculos para la realización del derecho al asilo de los NNA en México. VII. Reflexiones finales. V. Bibliografia.

\section{APROXIMACIÓN}

La llegada de Donald J. Trump a la presidencia de los Estados Unidos de América en enero de 2017 y la emisión de sus órdenes ejecutivas en materia de asilo ${ }^{1}$ han tenido una consecuencia positiva: han visibilizado la epopeya - a menudo con consecuencias terribles en términos de derechos humanos - a la que se enfrentan aquellos que buscan asilo. La indignación casi generalizada que éstas han generado parece, sin duda, justificada. Sin embargo, si hemos de ser coherentes, tenemos que enfrentar un hecho bochornoso: la situación de quiénes buscan asilo en México no sólo resulta deplorable, sino que permanece subanalizada e insuficientemente abordada. En México, aquel que busca asilo permanece en la penumbra, en los linderos entre el sistema legal y el aparato gubernamental del Ejecutivo federal que lo habita, relativamente oculto a la mirada pública. En estos

1 Las órdenes ejecutivas de Trump en materia de asilo pueden consultarse en: https:// wrwew.whitehouse.gov/briefing-room/presidential-actions/executive-orders (fecha de consulta: 31 de agosto de 2017).

Esta obra está bajo una Licencia Creative Commons

Atribución-NoComercial-SinDerivar 4.0 Internacional, IIJ-UNAM.

Boletín Mexicano de Derecho Comparado, núm. 152, pp. 707-739. 
intersticios prolifera la arbitrariedad, y los derechos humanos - en especial los de aquéllos más vulnerables - quedan siempre en entredicho.

Desde una perspectiva éticamente coherente y, por tanto, comprometida con el respeto irrestricto a los derechos humanos, no podemos permitirnos más esta invisibilidad. Sin embargo, traer esta situación a la luz resulta — sin duda - una tarea compleja. Por ejemplo, hablamos de "refugiados" para referir a aquellas personas que huyen de sus países de origen por amenazas contra su vida o seguridad. No obstante, la terminología misma parece participar en la opacidad. Al respecto, cabe hacer la siguiente precisión terminológica: ${ }^{2}$ asilo es la institución a través de la cual un Estado otorga protección, en su territorio o en otro lugar bajo el control de algunos de sus órganos, a una persona que se lo solicita. Entre las categorías de personas que reciben protección de un Estado a través de esta institución están: 1) los asilados políticos, ${ }^{3}$ a quienes el Estado les otorga protección al ser perseguidos por motivos políticos (pueden ser asilados políticos territoriales ${ }^{4}$ o diplomáticos), ${ }^{5}$ y 2) los refugiados, a quienes el Estado les puede

2 Para abundar sobre este tema, pueden consultarse, entre otros: San Juan, César Walter, "El asilo y la protección internacional de los refugiados en América Latina: análisis crítico del dualismo asilo-refugio a la luz del derecho internacional de los derechos humanos", en Franco, Leonardo (coord.), El asilo y la protección internacional de los refugiados en América Latina, Buenos Aires, Siglo XXI, 2003; Gil-Bazo, María Teresa y Nogueira, María Beatriz B., "El asilo en la práctica de los Estados de América Latina y África", Nuevos temas en la investigación sobre refugiados, Informe de investigación 249, ACNUR, 2013.

3 En general, véase Serrano Migallón, Fernando, El asilo politico en México, México, Porrúa, 1998.

4 En el asilo "territorial" los Estados admiten dentro de su territorio a las personas perseguidas políticamente, tal y como sucedió cuando el gobierno del presidente Lázaro Cárdenas dio asilo a los españoles que huyeron de la España franquista durante la Guerra Civil. Entre otros, véase Landa Landa, María Guadalupe et al., "El legado científico del exilio español en México a través de Ciencia", Revista Hispanoamericana de Ciencias Puras y Aplicadas, 2009, pp. 87-93; Pla, Dolores y Vázquez, Álvaro, El exilio español en la Ciudad de México, México, Turner, 2011.

5 El Estado puede otorgar el asilo "diplomático" en sus embajadas, legaciones, navíos de guerra, etcétera, sin necesidad de que la persona perseguida abandone el país del que desea salir. Según la Convención sobre Asilo Diplomático de 1954, "el asilo otorgado en legaciones, navíos de guerra y campamentos o aeronaves militares, a personas perseguidas por motivos o delitos políticos, será respetado por el Estado territorial de acuerdo con las disposiciones de la presente Convención. Para los fines de esta Convención, legación es toda sede de misión diplomática ordinaria, la residencia de los jefes de misión y los locales habilitados por ellos para habitación de los asilados cuando el número de éstos exceda de la capacidad normal de los edificios. Los navíos 
otorgar protección no sólo por ser perseguidos por motivos políticos, sino también por causa de raza, religión, nacionalidad, pertenencia a un determinado grupo, ${ }^{6}$ o vivir en un entorno de violencia generalizada, agresión extranjera, conflictos internos, violación masiva de derechos humanos u otras circunstancias que hayan perturbado gravemente el orden público. ${ }^{7}$

En México, quien pide asilo enfrenta obstáculos inclusive para su inserción dentro de la categoría de "refugiado", y en la ambigüedad entre categorías - en la arbitrariedad que sostiene sus linderos - apenas se recibe luz. En el extremo opuesto a la abstracción, la situación de quien pide asilo resulta precaria, ello en virtud de que la consigna de los Estados - tal parece- es impedirles o, de menos, dificultarles al máximo que se les reconozca, incluso, el ingreso al término "refugiados". Ésta es sólo la primera de una serie de negativas y opacidades a las que se enfrenta quien busca asilo y que, a menudo, resultan funestas. Como ha señalado Zeid Ra'ad Al Hussein, el alto comisionado de Derechos Humanos de la ONU: "estas personas tienen la muerte a sus espaldas y un muro en la cara". ${ }^{8}$

Estamos, pues, ante un derecho humano al asilo reconocido y refrendado por el Estado mexicano, ${ }^{9}$ pero, finalmente, vacío. Las regulaciones

de guerra o aeronaves militares que estuviesen provisionalmente en astilleros, arsenales o talleres para su reparación, no pueden constituir recinto de asilo" (artículo lo.). Un ejemplo de asilo diplomático es el que otorgó Ecuador a Julian Assange en 2012 en su embajada en Londres. Véase Zibell, Matías, “Qué llevó a Julian Assange a solicitar asilo a Ecuador?", BBC, 20 de junio de 2012, disponible en: http://wwrw.bbc.com/mun do/noticias/2012/06/120619_reino_unido_ecuador_assange_asilo_wikileaks_jg.shtml (fecha de consulta: 31 de agosto de 2017$)$.

6 Hasta aquí llegan los motivos autorizados por el artículo 1.A.2) de la Convención de 1951 sobre el Estatuto de los Refugiados de 1951.

7 Estos motivos forman parte de la definición ampliada de "refugiado" que establece la conclusión tercera de la Declaración de Cartagena sobre Refugiados de 1984.

8 Nebehay, Stephanie, "Few new Pledges at U. N. talks to resettle Syrian Refugees", Reuters, 30 de marzo de 2016, disponible en: http://wrwrereuters.com/article/us-mideast-crisissyria-refugees-idUSKCNOWWOL4 (fecha de consulta: 31 de agosto de 2017).

9 En México se reconoce la condición de refugiado de acuerdo con la siguiente regulación: A nivel internacional con la Convención sobre el Estatuto de los Refugiados de 1951 y el Protocolo sobre el Estatuto de los Refugiados de 1967, instrumentos respecto de los cuales México se encuentra obligado desde el 2000 (DOF, 25 de agosto de 2000). A nivel nacional con el segundo párrafo del artículo 11 de la Constitución (DOF, 15/08/2016 adicionado); la Ley sobre Refugiados, Protección Complementaria y Asilo Político $(D O F, 21$ de enero de 2011) y su Reglamento (DOF, 21 de febrero de 2011); y por todas aquellas normas de derechos humanos en atención al parámetro de regularidad constitucional (SCJN,

Esta obra está bajo una Licencia Creative Commons

Atribución-NoComercial-SinDerivar 4.0 Internacional, IIJ-UNAM.

Boletín Mexicano de Derecho Comparado, núm. 152, pp. 707-739. 
nacionales de los procedimientos de asilo evidencian que estas personas - sean niños, niñas, adolescentes o adultos - no son iguales en derechos que los nacionales o extranjeros en situación económica privilegiada. Los Estados han creado para ellos un estado de excepción permanente, como han señalado Sassen y Bauman, ${ }^{10}$ en diálogo con Agamben: ${ }^{11}$ un espacio de excepción en el que la ambigüedad suspende, de facto, el orden jurídico en materia de acceso a la justicia, debido proceso e igualdad ante la ley. La regulación actual del derecho al asilo en México muestra cómo se pueden contravenir los principios básicos del Estado de derecho y de derechos humanos mientras esto suceda en la penumbra, parcialmente fuera de escena. Quien busca asilo en México es admitido dentro un estado de excepción permanente que, como diría Lochak, ${ }^{12}$ se ha vuelto la regla. En suma, en tal penumbra excepcional, el derecho humano al asilo es un derecho vacío.

La situación demanda, entonces, métodos que neutralicen la opacidad de estos espacios de excepción, de modo tal que podamos iluminar y, potencialmente, modificar aquello que mantiene oculto de la mirada pública a quien pide asilo en México. Como primera aproximación, parece necesario delinear los linderos legales que dan forma a estos espacios en su dimensión jurídica, de manera que podamos aproximar los elementos que devienen en la construcción del derecho humano al asilo como vacío (o sin contenido) en nuestro país. Con esta finalidad, resulta útil enfocarse en un subconjunto de estas personas, uno caracterizado por su extrema vulnerabilidad: los niños, las niñas y los adolescentes (NNA).

El presente artículo, por tanto, tiene dos objetivos principales:

1. Sistematizar y, por tanto, hacer visible, el procedimiento legal al que tienen que enfrentarse los NNA que deciden pedir asilo en

1a. CGCXLIV/2015 (10a.). Primera sala, Libro 24, noviembre de 2015, t. I, 2010426, Décima Época) y del artículo 1o. constitucional: "En los Estados Unidos Mexicanos todas las personas gozarán de los derechos humanos reconocidos en esta Constitución y en los tratados internacionales de los que el Estado Mexicano sea parte...”.

10 Cfr. Sassen, S., Expulsions. Brutality and Complexity in the Global Economy, Cambridge, Harvard University Press, 2014; Bauman, Zygmunt, Archipiélago de excepciones, Buenos Aires, Katz, 2008.

11 Cfr. Agamben, Giorgio, Estado de excepción... cit.

12 Cfr. Lochak, Danièle, Face aux migrants: état de droit ou état de siège?, París, Textuel, 2007.

Esta obra está bajo una Licencia Creative Commons Atribución-NoComercial-SinDerivar 4.0 Internacional, IIJ-UNAM. Boletín Mexicano de Derecho Comparado, núm. 152, pp. 707-739. 
México y, en caso de recibir una negativa, impugnar esta decisión administrativa. Dada la opacidad de dicho procedimiento - regulado en seis distintas leyes federales y tres reglamentos $-^{13} \mathrm{y}$ la escasez de trabajo académico al respecto, resulta fundamental una descripción jurídica adecuada. En este sentido, es indispensable considerar que si el proceso legal puede parecer arcano para personas familiarizadas con temas migratorios o legales, lo es aún más para aquellos NNA que llegan a México en busca de asilo, la mayoría de las veces en condiciones muy precarias: huyendo de sus países de origen por amenazas contra su vida y su libertad, no acompañados y en un estatus migratorio irregular. ${ }^{14}$ Además, hay que recordar que el ordenamiento jurídico mexicano no provee asistencia jurídica gratuita para estos niños, niñas y adolescentes. ${ }^{15}$

De este modo, estamos hablando de un caso extremo: estos NNA se encuentran en estado de indefensión respecto al procedimiento de determinación de la calidad de refugiado al que se enfrentan. Por un lado, el proceso es confuso y burocrático, incluso para un adulto; y, por el otro, el acceso de estos NNA a los pormenores del proceso en sí es limitado. Las consecuencias del procedimiento, sin embargo, suelen ser bastante serias, independientemente de la edad de la persona solicitante. No resulta sorpresivo,

13 Ley sobre Refugiados, Protección Complementaria y Asilo Político de México; Ley de Migración; Ley Federal de Procedimiento Administrativo; Ley General de los Derechos de Niñas, Niños y Adolescentes; Ley Orgánica del Tribunal Federal de Justicia Administrativa; Ley de Amparo; Reglamento de la Ley de Migración; Reglamento de la Ley General de los Derechos de Niñas, Niños y Adolescentes, y Reglamento de la Ley sobre Refugiados y Protección Complementaria.

14 Por ejemplo, véanse en este sentido: ACNUR, Niños en fuga, Washington D.C., ACNUR, 2014; Médicos Sin Fronteras, Forzados a huir del Triángulo Norte de Centroamérica: una crisis humanitaria olvidada, Ciudad de México, Nueva York, Río de Janeiro, Barcelona, MSF, 2017, p. 8.

15 De acuerdo con la Ley General de los Derechos de Niñas, Niños y Adolescentes, todos los niños menores de 18 años tienen derecho a asistencia legal, pero no gratuita, y a comunicarse libremente con sus abogados. Artículo 92, fr. VII, Ley General de los Derechos de Niñas, Niños y Adolescentes. Este artículo no especifica que los NNA tengan derecho a asistencia legal gratuita, a diferencia de que sí establece su derecho a ser asistidos gratuitamente por un traductor y/o intérprete (artículo 92-V). También véase Ceriani Cernadas, Pablo (ed.), Niñez detenida, México, Argentina, Fontamara, 2012, p. 16.

Esta obra está bajo una Licencia Creative Commons

Atribución-NoComercial-SinDerivar 4.0 Internacional, IIJ-UNAM.

Boletín Mexicano de Derecho Comparado, núm. 152, pp. 707-739. 
considerado así, que el resultado agregado sea una colección sin fin de violaciones serias de derechos humanos de los NNA que buscan asilo en nuestro país.

2. Una vez clarificado el procedimiento para que los NNA obtengan asilo en México, el presente artículo identifica y analiza los obstáculos más notorios que la forma jurídica específica de este procedimiento produce en su práctica cotidiana. Esto con el fin de iluminar, desde una perspectiva crítica, la situación real del derecho al asilo de NNA en México y, a su vez, construir una base para poder plantear estrategias legales orientadas a solventar dichos obstáculos. De esta forma, busca contribuir a que, en un futuro, los NNA que buscan asilo en México puedan tener garantizado dicho derecho.

\section{EL DERECHO DE BUSCAR Y RECIBIR ASILO EN MÉXICO}

Regulación internacional, constitucional y legal del derecho al asilo

A nivel internacional, en el ámbito universal, el derecho de asilo está contemplado en el artículo 14 de la Declaración Universal de los Derechos Humanos de 1948, que a la letra dice: "(1) En caso de persecución, toda persona tiene derecho a buscar asilo, y a disfrutar de él, en cualquier país. (2) Este derecho no podrá ser invocado contra una acción judicial realmente originada por delitos comunes o por actos opuestos a los propósitos y principios de las Naciones Unidas".

En el ámbito del sistema interamericano de derechos humanos, del cual México es parte, este derecho se encuentra plasmado, primero, en el artículo XXVII de la Declaración Americana de los Derechos y Deberes del Hombre de 1948, el cual dispone que: "Toda persona tiene el derecho de buscar y recibir asilo en territorio extranjero, en caso de persecución que no sea motivada por delitos de derecho común y de acuerdo con la legislación de cada país y con los convenios internacionales". Y, segundo, en el artículo 22.7 de la Convención Americana sobre Derechos Humanos de 1969, que señala: "Toda persona tiene el derecho de buscar y recibir asilo en territorio extranjero en caso de persecución por delitos políticos o 
comunes conexos con los políticos y de acuerdo con la legislación de cada Estado y los convenios internacionales". ${ }^{16}$

Cabe recordar que, de acuerdo con el artículo 1o. de la Constitución, en México todas las personas gozan de los derechos humanos reconocidos tanto en la Constitución como en los tratados internacionales de los que el Estado mexicano sea parte, por lo que se puede señalar - sin titubeosque en México se encuentra reconocido el derecho humano al asilo.

A nivel constitucional el derecho al asilo está expresamente reconocido en el segundo párrafo del artículo $11,{ }^{17} \mathrm{el}$ cual dispone que: "Toda persona tiene derecho a buscar y recibir asilo. El reconocimiento de la condición de refugiado y el otorgamiento de asilo político, se realizarán de conformidad con los tratados internacionales. La ley regulará sus procedencias y excepciones".

A nivel legal, la Ley sobre Refugiados, Protección Complementaria y Asilo Político, ${ }^{18}$ de carácter federal, es la encargada de regular el derecho de asilo. Así, su artículo 3o. señala: "La presente Ley tiene por objeto regular el otorgamiento de asilo político, el reconocimiento de la condición de refugiado y el otorgamiento de protección complementaria, así como establecer las bases para la atención a los solicitantes y asistencia a los asilados y refugiados que se encuentran en territorio nacional, con la finalidad de garantizar el pleno respeto a sus derechos humanos". ${ }^{19}$ De este modo, en México se reconocen tres categorías relacionadas con el derecho de asilo: asilados políticos, refugiados y personas a quienes se les otorga protección complementaria.

16 Ratificada por México el 3 de febrero de 1981 y publicada en el Diario Oficial de la Federación el 7 de mayo de 1981.

17 Reformado mediante decreto publicado en el Diario Oficial de la Federación el 15 de agosto de 2016. El primer párrafo del artículo 11 señala: "Toda persona tiene derecho para entrar en la República, salir de ella, viajar por su territorio y mudar de residencia, sin necesidad de carta de seguridad, pasaporte, salvoconducto u otros requisitos semejantes. El ejercicio de este derecho estará subordinado a las facultades de la autoridad judicial, en los casos de responsabilidad criminal o civil, y a las de la autoridad administrativa, por lo que toca a las limitaciones que impongan las leyes sobre emigración, inmigración y salubridad general de la República, o sobre extranjeros perniciosos residentes en el país”. La redacción de este primer párrafo del artículo 11 es del año 2011, la cual quedó de esta manera en el marco de la reforma constitucional en materia de derechos humanos, publicada en el Diario Oficial de la Federación el 10 de junio de 2011.

18 Publicada en el Diario Oficial de la Federación el 27 de enero de 2011. Su reglamento fue publicado en el Diario Oficial de la Federación el 21 de febrero de 2012.

19 Artículo reformado Diario Oficial de la Federación, 30 de octubre de 2014.

Esta obra está bajo una Licencia Creative Commons

Atribución-NoComercial-SinDerivar 4.0 Internacional, IIJ-UNAM.

Boletín Mexicano de Derecho Comparado, núm. 152, pp. 707-739. 
Finalmente, es preciso señalar que diversas disposiciones establecidas en la Ley de Migración ${ }^{20}$ impactan la regulación del derecho de asilo en México, en virtud de que esta ley regula el ingreso, la salida, el tránsito y la estancia de extranjeros en el territorio nacional "en un marco de respeto, protección y salvaguarda de los derechos humanos, de contribución al desarrollo nacional y de preservación de la soberanía y la seguridad nacional". ${ }^{21}$ Además, la política general de inmigración incluye como principio operativo "el respeto irrestricto de los derechos humanos de los migrantes", con especial atención a grupos vulnerables, como los NNA, ${ }^{22}$ cuyo tratamiento específico como refugiados, en especial en cuanto a la protección contra la devolución se refiere, ${ }^{23}$ es complementado por las disposiciones de la Ley General de los Derechos de Niños, Niñas y Adolescentes. ${ }^{24}$

Asimismo, en el caso de los NNA solicitantes de asilo las autoridades mexicanas deben responder al "principio del interés superior del niño", con rango constitucional, ${ }^{25} \mathrm{y}$ a los tratados internacionales de derechos humanos de los que México es parte, ${ }^{26}$ especialmente, la Convención sobre los Derechos del Niño ${ }^{27}$ de 1989, la Convención sobre el Estatuto de los Refugiados de 1951, ${ }^{28}$ y la Convención Americana sobre Derechos Humanos de 1969. ${ }^{29}$

\section{III. ¿QUIÉN ES REFUGIADO EN MÉXICO?}

México reconoce a las personas refugiadas siguiendo criterios que coinciden con los establecidos internacionalmente, y respecto de los cuales se ha

\footnotetext{
20 Publicada en el Diario Oficial de la Federación el 25 de mayo de 2011.

21 Artículo 1o., Ley de Migración.

22 Artículo 2o., 66 y 67, Ley de Migración.

23 Artículos 89-101, Ley General de los Derechos de Niñas, Niños y Adolescentes.

24 Publicada en el Diario Oficial de la Federación, 4 de diciembre de 2014.

25 Artículo 73(XXIX-P), Constitución Política de los Estados Unidos Mexicanos (CPEUM).

26 Artículos 1o. y 133, CPEUM.

27 Adoptada en Nueva York el 20 de noviembre de 1989. México la ratificó el 19 de junio de 1990.

28 Adoptada en Ginebra el 28 de julio de 1951. México se adhirió el 7 de junio de 2000.

29 Adoptada en San José el 22 de noviembre de 1969. México se adhirió el 2 de marzo de 1981 .
} 
obligado: en la Convención sobre el Estatuto de los Refugiados de 1951, el Protocolo sobre el Estatuto de los Refugiados de $1967^{30}$ y la Declaración de Cartagena de $1984 .{ }^{31}$ De este modo, de acuerdo con el artículo 13, fracciones I y II, de la Ley sobre Refugiados, Protección Complementaria y Asilo Político, es refugiado:

a) Quien por temores fundados de ser perseguido por motivos de raza, religión, nacionalidad, género, ${ }^{32}$ pertenencia a determinado grupo social u opiniones políticas, se encuentre fuera del país de su nacionalidad y no puede a causa de dichos temores, o no quiera acogerse a la protección de tal país; o que, careciendo de nacionalidad y hallándose, a consecuencia de tales acontecimientos, fuera del país donde antes tuviera su residencia habitual, no pueda o, a causa de dichos temores, no quiera regresar a él. ${ }^{33}$

b) Quien ha huido de su país porque su vida, seguridad o libertad han sido amenazadas por la violencia generalizada, la agresión extranjera, los conflictos internos, la violación masiva de los derechos humanos u otras circunstancias que hayan perturbado gravemente el orden público. ${ }^{34}$

Además, tanto la Ley de Refugiados, Protección Complementaria y Asilo Político como la Ley de Migración ${ }^{35}$ otorgan la posibilidad de otorgar "protección complementaria" para las situaciones en las que la vida de una persona extranjera se vería amenazada, a pesar de no encontrarse

30 Adoptado en Nueva York el 31 de enero de 1967. México se adhirió el 7 de junio de 2000 .

31 Adoptada por el "Coloquio Sobre la Protección Internacional de los Refugiados en América Central, México y Panamá: Problemas Jurídicos y Humanitarios”, celebrado en Cartagena, Colombia, del 19 al 22 de noviembre de 1984.

32 La razón de "género" no está establecida en el artículo 1o. de la Convención de Refugiados del 1951, pero sí está establecida en la ley mexicana.

33 Artículo lo., Convención sobre el Estatuto de los Refugiados, de 28 de julio de 1951. México se adhirió el 7 de junio de 2000 a esta Convención. Artículo 13, fr. 1, Ley sobre Refugiados, Protección Complementaria y Asilo Político de México.

34 Véase Declaración de Cartagena sobre Refugiados de 1984, conclusión 3; y Ley sobre refugiados, protección complementaria y asilo político, artículo 13 (2).

35 Publicada en el Diario Oficial de la Federación, 25 de mayo de 2011.

Esta obra está bajo una Licencia Creative Commons

Atribución-NoComercial-SinDerivar 4.0 Internacional, IIJ-UNAM.

Boletín Mexicano de Derecho Comparado, núm. 152, pp. 707-739. 
bajo los supuestos que la calificarían como refugiada, o estaría en peligro de ser sometida a tortura u otros malos tratos. ${ }^{36} \mathrm{Y}$ la Ley de Migración prevé la posibilidad de otorgar una "visa humanitaria", vigente por un año, por ejemplo para los NNA no acompañados, así como aquellos migrantes víctima de delitos graves en México (por ejemplo, extorsión, secuestro, violencia sexual y de otro tipo, trata, explotación laboral y otros abusos cometidos por criminales, pandillas locales y operaciones del crimen organizado). ${ }^{37}$

\section{PROCEDIMIENTO PARA QUE LOS NNA SOLICITEN ASILO EN MÉXICO}

\section{Reglas procedimentales}

Los NNA no acompañados no sólo tienen derecho a solicitar asilo en México, sino a que sus peticiones sean atendidas de manera prioritaria. ${ }^{38}$ Aún más, está específicamente prohibida la devolución, expulsión o deportación de todos los niños menores de 18 años cuando su vida, seguridad o libertad estén en peligro a causa de la persecución o la amenaza de la misma, la violencia generalizada o las violaciones masivas de los derechos humanos, así como donde puedan ser sometidos a la tortura y otros tratos crueles, inhumanos o degradantes. ${ }^{39}$ Sin embargo, hay que señalar que la substanciación concreta de este procedimiento frecuentemente dista de lo que manda la norma. Esto justifica, sin duda, la necesidad de una descripción detallada.

Cualquier funcionario gubernamental que tenga conocimiento de la pretensión de una persona extranjera de solicitar asilo deberá dar aviso por escrito a la Comisión Mexicana de Ayuda al Refugiado (Comar) en un plazo de 72 horas. ${ }^{40}$ Sin embargo, bajo el Reglamento de la Ley Ge-

\footnotetext{
36 Artículos 28, Ley sobre Refugiados, Protección Complementaria y Asilo Político; artículo 3o., fr. XXI, Ley de Migración.

37 Artículos 52, fr. V, y 74, Ley de Migración.

38 Artículo 35, Ley sobre Refugiados, Protección Complementaria y Asilo Político.

39 Artículo 96, Ley General de los Derechos de Niños, Niñas y Adolescentes.

40 Artículo 21, Ley sobre Refugiados, Protección Complementaria y Asilo Político; artículo 18, Reglamento de la Ley sobre Refugiados y Protección Complementaria.
} 
neral de los Derechos de Niñas, Niños y Adolescentes, ${ }^{41}$ el Sistema para el Desarrollo Integral de la Familia (DIF) también debe dar aviso en un plazo de 48 horas - en lugar de 72 horas - tanto al Instituto Nacional de Migración (INM) como a la Comar, cuando estime que existen elementos que presuman que un niño, una niña o un adolescente migrante es susceptible de que se le reconozca la condición de refugiado, asilado político o necesitado de protección complementaria.

El INM no sólo está obligado a recibir y remitir las solicitudes de reconocimiento de la condición de refugiado ${ }^{42}$ sino también a identificar a las posibles personas solicitantes de asilo, informándoles sobre su derecho de solicitarlo. ${ }^{43} \mathrm{Y}$ debe colaborar con la Comar para garantizar que cada una de ellas reciba la constancia de que su solicitud está siendo tramitada. ${ }^{44}$ El DIF está sujeto a obligaciones similares. ${ }^{45}$ Además, el INM debe ayudar en la canalización de los solicitantes en situación de vulnerabilidad a instituciones especializadas. ${ }^{46}$ Es decir, los NNA no acompañados menores de 18 años o las familias que viajan con NNA deben ser transferidos de los centros de detención migratoria a albergues del DIF. Sin embargo, en la práctica, muchos NNA no acompañados y familias con hijos e hijas de todas las edades permanecen en detención migratoria hasta que sus solicitudes son resueltas o aceptan la devolución a sus países de origen. ${ }^{47}$

Las solicitudes de asilo deben ser presentadas en un plazo de 30 días hábiles. ${ }^{48}$ Las normas aplicables permiten que la Comar acepte solicitudes fuera del plazo de 30 días bajo circunstancias excepcionales, cuando la persona solicitante sea incapaz de presentar la solicitud por razones

41 Artículo 109, Reglamento de la Ley General de los Derechos de Niñas, Niños y Adolescentes.

42 Artículos 16, fr. II, y 17, Reglamento de la Ley sobre Refugiados y Protección Complementaria.

43 Artículo 16, fr. I, Reglamento de la Ley sobre Refugiados y Protección Complementaria.

44 Artículo 16, fr. III, Reglamento de la Ley sobre Refugiados y Protección Complementaria.

45 Artículo 109, Reglamento de la Ley General de los Derechos de Niñas, Niños y Adolescentes.

46 Artículos 16, fr. V, Reglamento de la Ley sobre Refugiados y Protección Complementaria.

47 Sin Fronteras IAP, La ruta del encierro, México, Sin Fronteras IAP, 2014, p. 50.

48 Artículo 18, Ley sobre Refugiados, Protección Complementaria y Asilo Político.

Esta obra está bajo una Licencia Creative Commons

Atribución-NoComercial-SinDerivar 4.0 Internacional, IIJ-UNAM.

Boletín Mexicano de Derecho Comparado, núm. 152, pp. 707-739. 
fuera de su control. ${ }^{49}$ Estas solicitudes pueden ser presentadas verbalmente ${ }^{50} \mathrm{y}$ en cualquier idioma. ${ }^{51}$ Las personas solicitantes tienen derecho de recibir "información clara, oportuna y gratuita sobre el procedimiento de reconocimiento de la condición de refugiado". ${ }^{52}$ Aquellas que no hablan español tienen derecho a un traductor o intérprete ${ }^{53}$ de forma gratuita. ${ }^{54}$ Los NNA migrantes no acompañados o separados de sus familias "que requieren servicios para su protección" deben recibir asistencia adicional. ${ }^{55}$ De acuerdo con la Ley General de los Derechos de Niñas, Niños y Adolescentes, todos los NNA menores de 18 años tienen derecho a asistencia legal, pero no gratuita, y a comunicarse libremente con sus abogados. ${ }^{56}$

Una vez que la solicitud ha sido formalmente presentada, ninguna autoridad puede proporcionar información o notificar a las autoridades diplomáticas o consulares del país de origen de la persona solicitante, a menos que se cuente con evidencia del consentimiento de ésta. ${ }^{57}$ Cuando la solicitud está en trámite, todos los procedimientos migratorios por ingreso irregular son suspendidos, y la persona solicitante no puede ser devuelta a su país de origen. ${ }^{58}$

Las personas solicitantes son entrevistadas por la Comar, con la asistencia de un intérprete en caso necesario. ${ }^{59}$ Quienes acompañen a los anteriores deben tener la oportunidad de ser entrevistadas individual-

49 Artículo 19, Reglamento de la Ley sobre Refugiados y Protección Complementaria.

50 Artículo 18, Ley sobre Refugiados, Protección Complementaria y Asilo Político.

51 Artículo 17, fr. II, Reglamento de la Ley sobre Refugiados y Protección Complementaria.

52 Artículo 19, Ley sobre Refugiados, Protección Complementaria y Asilo Político; artículo 13, fr. III, Ley de Migración.

53 Artículo 14, Ley de Migración.

54 Artículo 92, fr. V, Ley General de los Derechos de Niñas, Niños y Adolescentes.

55 Artículo 29, fr. I, Ley de Migración.

56 Artículo 92, fr. VII, Ley General de los Derechos de Niñas, Niños y Adolescentes. Este artículo no especifica que los NNA tengan derecho a asistencia legal gratuita, a diferencia de que sí establece su derecho a ser asistidos gratuitamente por un traductor y/o intérprete (artículo 92, fr. V).

57 Artículo 21, Ley sobre Refugiados, Protección Complementaria y Asilo Político; artículos 22 y 28, Reglamento de la Ley sobre Refugiados y Protección Complementaria.

58 Artículo 7o., Ley sobre Refugiados, Protección Complementaria y Asilo Político; artículo 22, Reglamento de la Ley sobre Refugiados y Protección Complementaria.

59 Artículos 29 y 30, Reglamento de la Ley sobre Refugiados y Protección Complementaria. 
mente con el propósito de determinar si pueden presentar una solicitud independiente. ${ }^{60}$

\section{DETERMINAGIÓN DE LA CONDICIÓN DE REFUGIADO POR PARTE DE LA COMAR}

La Comar decide tanto las solicitudes de asilo como las de protección complementaria. ${ }^{61}$ Para ello, tiene 45 días hábiles, que pueden ser prorrogados por otros 45 días más, para resolver la solicitud. ${ }^{62}$ Las personas solicitantes deben recibir notificación por escrito dentro de los 10 días hábiles siguientes a la emisión de la resolución. ${ }^{63}$ Las solicitudes para protección complementaria son consideradas en el mismo proceso que las solicitudes de reconocimiento de la condición de refugiado: una persona solicitante que no reúne los requisitos para ser reconocida como refugiada es evaluada para ver si requiere protección complementaria antes de emitirse la resolución final. ${ }^{64} \mathrm{~A}$ las personas extranjeras reconocidas como refugiadas y a aquéllas que reciben protección complementaria se les otorga la condición de residentes permanentes. ${ }^{65}$

\section{Recurso de revisión ante la Comar por la negación de la calidad de refugiado: primera instancia}

Las personas solicitantes de asilo a quienes no se les reconoció la condición de refugiadas ni se les concedió protección complementaria pueden interponer un recurso de revisión, ${ }^{66}$ pero ante la misma Co-

60 Artículo 31, Reglamento de la Ley sobre Refugiados y Protección Complementaria.

61 Artículos 15, frs. II, III, V, y 48 a 50, Reglamento de la Ley sobre Refugiados y Protección Complementaria.

62 Artículo 24, Ley sobre Refugiados, Protección Complementaria y Asilo Político; artículos 45 y 47, Reglamento de la Ley sobre Refugiados y Protección Complementaria.

63 Artículo 45, Reglamento de la Ley sobre Refugiados y Protección Complementaria.

64 Artículo 29, Ley sobre Refugiados, Protección Complementaria y Asilo Político; y artículo 46, Reglamento de la Ley sobre Refugiados y Protección Complementaria.

65 Artículo 54, fr. I, Ley de Migración; artículo 87, Reglamento de la Ley sobre Refugiados y Protección Complementaria.

66 Artículo 25, Ley sobre Refugiados, Protección Complementaria y Asilo Político; artículo 59, Reglamento de la Ley sobre Refugiados y Protección Complementaria, que

Esta obra está bajo una Licencia Creative Commons

Atribución-NoComercial-SinDerivar 4.0 Internacional, IIJ-UNAM.

Boletín Mexicano de Derecho Comparado, núm. 152, pp. 707-739. 
mar. ${ }^{67}$ Es decir, el mismo órgano administrativo que decidió si les otorgaba la calidad de refugiadas o protección complementaria revisa su propia decisión: es juez y parte en el mismo proceso. La práctica demuestra, tal vez sin mucha sorpresa, que en la mayoría de los casos la decisión inicial es confirmada en esta revisión administrativa por la misma Comar. ${ }^{68}$ El plazo para interponer el recurso de revisión es de 15 días hábiles, contados a partir del día siguiente a aquél en el que surtió efectos la notificación de la resolución respectiva, ${ }^{69}$ y se substancia de acuerdo con lo que señala la Ley Federal de Procedimiento Administrativo.

\section{Fuicio contencioso administrativo ante el Tribunal Federal de Fusticia Administrativa (TFJA): segunda instancia}

Las personas solicitantes de asilo cuyos recursos de revisión fueron negados por la Comar (poniéndose, de este modo, fin al procedimiento administrativo para la determinación de la calidad de refugiado) pueden

señala: "En contra de la negativa de reconocimiento de la condición de refugiado, de la cesación, de la cancelación, de la revocación o del retiro de la protección complementaria, de la negativa de autorización de reunificación familiar, así como del dictamen sobre la protección efectiva a que se refiere el artículo 91 de este Reglamento, procede el recurso de revisión". Y el artículo 83 de la Ley Federal de Procedimiento Administrativo, el cual señala: "los interesados afectados por los actos y resoluciones de las autoridades administrativas que pongan fin al procedimiento administrativo, a una instancia o resuelvan un expediente, podrán interponer el recurso de revisión o, cuando proceda, intentar la vía jurisdiccional que corresponda".

$67 \mathrm{Al}$ respecto, el artículo 86 de la Ley Federal de Procedimiento Administrativo dispone: "El escrito de interposición del recurso de revisión deberá presentarse ante la autoridad que emitió el acto impugnado y será resuelto por el superior jerárquico, salvo que el acto impugnado provenga del titular de una dependencia, en cuyo caso será resuelto por el mismo".

68 En este sentido, es sumamente ilustrativo el trabajo UIA, CDHFMC, La interpretación y aplicación del derecho internacional y nacional de los refugiados. Análisis de las resoluciones de primera instancia de la Comisión Mexicana de Ayuda a Refugiados, México, UIA, CDHFMC, 2017. También véanse: Human Rights Watch, Puertas cerradas. El fracaso de México a la hora de proteger a niños refugiados y migrantes de América Central, EUA, HRW, 2016, p. 120; Sin fronteras IAP, Evolución y retos del asilo en México. 20 años de asistencia legal e incidencia por las personas refugiadas, México, Sin Fronteras, 2016, p. 54.

69 Artículo 25, Ley sobre Refugiados, Protección Complementaria y Asilo Político; artículo 60, Reglamento, Ley sobre Refugiados y Protección Complementaria, y artículo 85, Ley Federal de Procedimiento Administrativo.

Esta obra está bajo una Licencia Creative Commons Atribución-NoComercial-SinDerivar 4.0 Internacional, IIJ-UNAM. Boletín Mexicano de Derecho Comparado, núm. 152, pp. 707-739. 
impugnar la referida revisión administrativa ante el Tribunal Federal de Justicia Administrativa (TFJA), a través de la interposición de un juicio contencioso administrativo. Éste puede nulificar, revocar o modificar el acto de autoridad que se impugna, esto es, la negación de la calidad de refugiado hecha por la Comar. ${ }^{70}$

\section{Fuicio de amparo ante el Poder Fudicial de la Federación $(P f F)$ : tercera instancia}

Ya que la persona solicitante de asilo ha agotado las dos instancias disponibles para impugnar la decisión que le niega la calidad de refugiada, puede intentar, como última opción, la vía judicial, a través de la interposición de un juicio de amparo. ${ }^{71}$ Para ello, es preciso que haya agotado previamente los recursos ordinarios que se establecen en la ley de la materia. Esto en virtud de que el juicio de amparo es improcedente en contra de las resoluciones de tribunales administrativos, en este caso el TFJA, respecto de las cuales la ley ordinaria - la Ley Federal de Procedimiento Administrativo (LFPA) - conceda algún recurso o medio de defensa - el juicio contencioso administrativo - por virtud del cual el acto reclamado - negación de la calidad de refugiado - pueda ser modificado, revocado o nulificado. Ahora bien, es preciso destacar que se puede intentar interponer un juicio de amparo obviando la segunda instancia - es decir, la del TFJA - ya que la Ley de Amparo dispone que pueden constituir una excepción al principio de agotabilidad de los recursos ordinarios las situaciones que entrañen el riesgo de la privación de la vida, deportación o expulsión, como podría ser la negación de la calidad de refugiado y la consecuente deportación al país de origen. ${ }^{72}$

A pesar de que el ordenamiento jurídico mexicano prevé que la persona solicitante de asilo rechazada pueda interponer el juicio de amparo en tercera instancia, la situación, como he intentado ilustrar, dista de ser sencilla para la persona solicitante. Primero, constituye una traba consi-

70 Artículo 83, Ley Federal de Procedimiento Administrativo; artículo 3o., fr. XII, Ley Orgánica del Tribunal Federal de Justicia Administrativa.

71 Artículos 103 y 107, CPEUM.

72 Artículo 61, fr. XVIII, inc. a, Ley de Amparo, reglamentaria de los artículos 103 y 107 de la Constitución Política de los Estados Unidos Mexicanos, publicada en el Diario Oficial de la Federación del 2 de abril de 2013.

Esta obra está bajo una Licencia Creative Commons

Atribución-NoComercial-SinDerivar 4.0 Internacional, IIJ-UNAM.

Boletín Mexicano de Derecho Comparado, núm. 152, pp. 707-739. 
derable al acceso a la justicia que las personas solicitantes de asilo tengan que acudir primero a dos instancias administrativas imposibilitadas para interpretar y decidir de acuerdo con las circunstancias particulares del caso antes de que puedan llegar a la revisión judicial, especialmente cuando se trata de personas tan vulnerables como los NNA no acompañados, sin recursos económicos y sin representación legal. Aún en el caso excepcional en el que se intente directamente el amparo, saltándose la segunda instancia del TFJA, es preciso considerar que, para interponer un juicio de amparo, se requiere un entrenamiento jurídico especializado. Las personas solicitantes rara vez cuentan con este conocimiento. Más aún, ante el vacío en términos de asistencia gubernamental, la sociedad civil organizada es la única que provee alguna asesoría legal al solicitante. ${ }^{73}$ Sin embargo, las organizaciones que toman la defensa de los casos de los NNA no acompañados, a pesar de su determinación - insuficientemente elogiable-, muy a menudo carecen del presupuesto y el personal especializado necesario, una faceta más de la opacidad sistémica que define el procedimiento de determinación de la calidad de refugiado en México. Si hemos de neutralizarla, resulta indispensable analizar las barreras que enfrenta quien busca asilo, en especial aquellas personas en situación más vulnerable como los NNA.

\section{OBSTÁCULOS PARA LA REALIZACIÓN DEL DERECHO AL ASILO DE LOS NNA EN MÉXICO}

\section{Obstáculos prácticos}

\section{A. Incumplimiento de la obligación de informar a los $\mathcal{N N A}$ sobre su derecho de solicitar asilo}

Los agentes del INM están obligados a recibir y remitir las solicitudes de asilo que se les presenten,$^{74}$ además de que tienen la responsabilidad de identificar de manera proactiva a posibles solicitantes del reconoci-

73 Por ejemplo, Clínica Jurídica para Refugiados Alaíde Foppa de la UIA, Centro de Derechos Humanos Fray Matías, FM4 Paso Libre o Sin Fronteras IAP.

74 Artículo 16, fr. I, Reglamento de la Ley sobre Refugiados y Protección Complementaria, y artículo 228, Reglamento de la Ley de Migración.

Esta obra está bajo una Licencia Creative Commons Atribución-NoComercial-SinDerivar 4.0 Internacional, IIJ-UNAM. Boletín Mexicano de Derecho Comparado, núm. 152, pp. 707-739. 
miento de la condición de refugiado e informarles sobre su derecho a solicitar asilo. ${ }^{75}$ El cumplimiento de esta responsabilidad frente a los NNA requiere que los Oficiales de Protección a la Infancia (OPI) y otros agentes del INM enfoquen con una sensibilidad especial la manera en la que los NNA pueden responder a sus preguntas y que hagan esfuerzos por examinar sus posibles necesidades de protección.

Sin embargo, con frecuencia, los agentes del INM que aprehenden a NNA no acompañados incumplen con su deber de informarles sobre su derecho a solicitar asilo ${ }^{76}$ y no tratan sus peticiones verbales de protección como solicitudes de reconocimiento de la condición de refugiado, a pesar de que están obligados por ley a hacerlo. Esto es ilegal de acuerdo con el artículo 92.2 de la Ley General de los Derechos de Niñas, Niños y Adolescentes que establece que los NNA tienen el derecho de ser informados de sus derechos en los procedimientos de inmigración, incluido su derecho de solicitar asilo. ${ }^{77}$ De hecho, la práctica común es que no se les informe apropiadamente sobre el proceso migratorio al que están siendo sujetos (información básica como los motivos de su detención o de su traslado de un centro de detención a otro, etcétera), ni sobre sus derechos y obligaciones, ni de forma escrita, ni verbal, ni de las alternativas existentes a la deportación. ${ }^{78}$

75 Artículo 16, fr. I, Reglamento de la Ley sobre Refugiados y Protección Complementaria, y artículo 173, Reglamento de la Ley de Migración: los agentes del INM también deben identificar a los niños que han sido víctimas o testigos de "algún delito en el país de origen o residencia habitual o en el territorio nacional".

76 ACNUR, Arrancados de raíz, México, ACNUR, 2014, p. 14, 61; Georgetown Law Human Rights Institute, The Cost of Stemming the Tide: How Immigration Enforcement Practices in Southern Mexico Limit Migrant Children's Access to International Protection, Washington DC, Georgetown University, 2015, p. 48.

77 Reglamento de la Ley sobre Refugiados y Protección Complementaria, artículos 16, fr. I, y 17, Diario Oficial de la Federación, 23 de febrero de 2012.

78 Véase Knippen, Jose et al., Un camino incierto: Fusticia para delitos y violaciones a los derechos humanos contra personas migrantes y refugiadas en México, México, Fundar, Casa del Migrante de Saltillo "Frontera con Justicia", 2015, p. 31; Centro de Derechos Humanos Fray Matías de Córdova, "Tapachula, Chiapas: La experiencia de detención en la frontera sur mexicana", en Barja Coria, Joselin, Derechos cautivos. La situación de las personas migrantes y sujetas a protección internacional en los centros de detención migratoria: siete experiencias de monitoreo desde la sociedad civil, México, Frontera con Justicia, 2015, p. 61; Comisión Interamericana de Derechos Humanos, Derechos humanos de los migrantes y otras personas en el contexto de la movilidad humana en México, Washington DC, CIDH, 2013, párr. 520, 535; Litigio Estratégico en Derechos 


\section{B. Falta de personal idóneo que evalúe adecuadamente las necesidades de protección internacional de los $\mathcal{N N A}$}

El INM cuenta con Oficiales de Protección a la Infancia (OPI) para llevar a cabo evaluaciones del interés superior de NNA y determinar sus necesidades de protección. Sin embargo, la mayoría de los NNA no entra en contacto con los OPI al momento de ser detenidos. ${ }^{79}$ Esto puede explicarse, al menos, por tres razones: 1) porque hay muy pocos agentes de protección a la infancia para la cantidad creciente de NNA migrantes no acompañados presentes en el país; ${ }^{30}$ 2) porque a estos funcionarios se les asignan otras responsabilidades administrativas que les dejan poco tiempo para llevar a cabo su misión de protección a la infancia, ${ }^{81}$ y 3 ) porque los agentes de protección a la infancia son, a la vez, agentes del INM, la agencia encargada de devolver a esos NNA a sus países de origen, lo cual crea un conflicto de intereses: los OPI son juez y parte en el mismo proceso. $^{82}$

Los NNA solicitantes de asilo no siempre explican con detalle las razones por las cuales abandonaron sus países, especialmente si no distinguen a las autoridades de protección infantil del INM (OPI) de los agentes de inmigración del INM ${ }^{83}$ Esto puede llevar a que den información falsa

Humanos, En tierra de nadie. El laberinto de la impunidad: violaciones de los derechos humanos de las personas migrantes en la región del Soconusco, México, i(dh)eas, 2011, p. 39; Instituto para la Seguridad y la Democracia, Diagnóstico del Instituto Nacional de Migración: hacia un sistema de rendición de cuentas en pro de los derechos humanos de las personas migrantes en México, México, Insyde, 2013, pp. 337-340.

79 ACNUR, Arrancados de raíz..., cit., p. 62; Musalo, Karen et al., Niñez y migración en Centro y Norte América: causas, políticas, prácticas y desafios, San Francisco y Buenos Aires, Center for Gender and Refugee Studies-UG Hastings-Universidad Nacional de Lanús, 2015, p. 273; Georgetown Law Human Rights Institute, The Cost of Stemming the Tide... cit., p. 45 .

80 Insyde, Diagnóstico del Instituto Nacional de Migración... cit., pp. 243 y 244.

81 Ibidem, p. 246; Georgetown Law Human Rights Institute, The Cost of Stemming the Tide..., cit., p. 46.

82 AGNUR, Arrancados de raíz..., cit., p. 62; Insyde, Diagnóstico del Instituto Nacional de Migración..., cit., p. 245. ACNUR, Niñez detenida, cit., cap. 3, pp. 15 y 16; Lorente, Diego, Morales, Gabriela, "Introducción a los capítulos sobre niños en el contexto de la migración en México, dos fronteras: una sola niñez", en Musalo, Karen et al., op. cit., p. 210.

83 Una crítica fundada sobre la función de los OPI y sus debilidades institucionales puede encontrarse en CNDH, Informe sobre la problemática de niñas, niños y adolescentes cen- 
debido a malentendidos, especialmente si se sienten coaccionados, o a que no proporcionen la información solicitada porque no la conocen. Tal y como señalan las directrices del ACNUR para las solicitudes de asilo de niños: "Los niños no pueden articular sus solicitudes de la condición de refugiado en la misma forma que los adultos y, por lo tanto, pueden requerir especial asistencia para llevarla a cabo". ${ }^{84}$

\section{Respuestas de los oficiales del INM que disuaden a NNA de solicitar protección internacional}

Es común que los agentes del INM respondan a las interrogantes de los potenciales solicitantes de asilo, sean adultos o NNA, con indiferencia, desincentivando que presenten su solicitud, con el pretexto de que no tienen pruebas suficientes o que las que tienen serán infructuosas, o sugiriéndoles que no soliciten asilo ya que eso resultaría en una prolongación indeterminada de su detención, ya que tienen que permanecer detenidos en la estación migratoria durante todo el tiempo que dure el procedimiento de reconocimiento de la condición de refugiado. ${ }^{85}$ Sin embargo, esto es ilegal, ya que los agentes del INM no están capacitados para prejuzgar las solicitudes de reconocimiento de la condición de refugiado. Es la Comar, la agencia que tiene la responsabilidad de determinar, después de una investigación en profundidad, si un solicitante es un refugiado o no. ${ }^{86}$ Estas respuestas de los agentes del INM violan su obligación de recibir y remitir inmediatamente las solicitudes de asilo a la Comar. ${ }^{87}$

troamericanos en contexto de migración internacional no acompañados en su tránsito por México, y con necesidades de protección internacional, México, CNDH, 2016, p. 78 y ss.

84 ACNUR, Directrices sobre protección internacional: Solicitudes de asilo de niños bajo los artículos 1(A)2 y 1(F) de la Convención de 1951 y/o el Protocolo de 1967 sobre el Estatuto de los Refugiados ("directrices sobre solicitudes de asilo de niños"), UN Doc. HCR/GIP/09/08, 22 de noviembre de 2009, párr. 2.

85 Comisión Interamericana, Derechos humanos de los migrantes y otras personas en el contexto de la movilidad humana..., cit., párr. 536; Human Rights Watch, Puertas cerradas..., cit., p. 62.

86 Artículos 15, fr. I, y 21, Ley sobre refugiados, protección complementaria y asilo político; y artículo 15, fr. III, Reglamento sobre la Ley sobre refugiados y protección complementaria.

87 Artículos 69, fr. IV, 109, fr. II, y 112, frs. II, III y V, Ley de Migración.

Esta obra está bajo una Licencia Creative Commons

Atribución-NoComercial-SinDerivar 4.0 Internacional, IIJ-UNAM.

Boletín Mexicano de Derecho Comparado, núm. 152, pp. 707-739. 


\section{Poca capacidad operativa y financiera del órgano encargado de decidir las solicitudes de asilo}

Desde 2014 México ha incrementado su énfasis en el control migratorio, según indican el aumento de la financiación dedicada a este propósito y el mayor número de aprehensiones y deportaciones realizadas. ${ }^{88}$ Sin embargo, no ha destinado recursos adicionales a la agencia de refugiados de México. En los últimos años, la Comar no ha tenido ningún aumento en la dotación de su personal, a pesar de que el número de casos que debe gestionar casi se ha duplicado desde 2013. Hasta julio de 2015, la Comar contaba con sólo 15 funcionarios que estuvieran capacitados para realizar determinaciones en los casos de peticiones de reconocimiento de la condición de refugiado. ${ }^{89}$ Aún más, hay 28 estados sin presencia de la Comar, teniendo sólo presencia en la Ciudad de México, Veracruz, Tabasco y Chiapas. ${ }^{90}$ En consecuencia, para una persona solicitante de asilo que se encuentra detenida en una estación migratoria donde no hay una oficina de la Comar, lleva más tiempo que su caso sea visto.

\section{E. La "alternativa" dada por Comar: "huida interna"}

Una de las razones comunes que argumenta la Comar para negar la condición de refugiado a los NNA en México es la posibilidad de encontrar algún lugar seguro dentro del mismo país del que vienen huyendo. Esta noción de "alternativa de huida interna" ${ }^{91}$ ha sido utilizada por otros gobiernos, incluyendo el de Estados Unidos, para denegar asilo a perso-

88 Segob, Unidad de Política Migratoria, Boletín Mensual de Estadísticas Migratorias 2016, México, 2016, p. 130. Los boletines estadísticos 2013, 2014 y 2015 pueden consultarse en: http://wrwr.politicamigratoria.gob.mx/es_mx/SEGOB/Boletines_Estadisticos (fecha de consulta: 31 de agosto de 2017).

89 Ureste, Manu, "México recibe 67\% más solicitudes de refugio, pero sólo tiene 15 oficiales para atender 2 mil casos", Animal Politico, 19 de junio de 2015, disponible en: http://wrew.animalpolitico.com/2015/06/mexico-recibe-67-mas-de-solicitudes-de-refugio-pero-solotiene-15-oficiales-de-comar-para-atender-2-mil-casos (fecha de consulta: 31 de agosto de 2017).

$90 \mathrm{Al}$ respecto, véanse las oficinas y delegaciones de COMAR en http://wrerr.comar. gob.mx/en/COMAR/Oficinas. A agosto de 2017, la oficina más reciente de COMAR era la ubicada en Tenosique, Tabasco.

91 ACNUR, Directrices sobre Protección Internacional núm. 4: La "alternativa de huida interna o reubicación" en el contexto del artículo $1 A$ (2) de la Convención de 1951 o el Protocolo de 1967 sobre el 
nas que, de otro modo, podrían haberlo recibido. Bajo este concepto, la persona solicitante es reconocida por tener una solicitud de asilo válida, pero basada en una amenaza local. Esto sugiere que la persona amenazada podría haber huido a otra zona más segura dentro de su país de origen, por lo que la solicitud de asilo puede ser denegada y la persona puede ser devuelta a su patria, para convertirse, sobra decir, en un desplazado interno. ${ }^{92}$ Ahora bien, cuando hablamos de los países del Triángulo Norte de Centroamérica, particularmente relevante en el caso de México, como señala el ACNUR, "es virtualmente inconcebible que una persona o una familia entera pueda escapar de las maras mediante una simple reubicación y empezar una nueva vida sin miedo a las represalias". ${ }^{93}$ Aún más, "dado que muchas pandillas centroamericanas, tales como las maras, tienen una organización de alcance nacional e incluso regional, generalmente no puede haber ninguna alternativa realista de huida interna en estas solicitudes relacionadas a estas pandillas". ${ }^{94}$

\section{Obstáculos jurídicos}

\section{A. Falta de representación jurídica gratuita a NNA solicitantes de asilo}

Los procedimientos para la resolución de las solicitudes de asilo son confusos y no están adaptados para que puedan ser completados por NNA sin ayuda. Es decir, resultan prohibitivamente opacos. Sin embargo, México no proporciona representación legal gratuita a nadie, sean NNA o adultos. ${ }^{95}$ Como resultado, los NNA que consiguen pedir asilo deben

Estatuto de los Refugiados, HCR/GIP/03/04, 23 de julio de 2003, disponible en: http://wrere. acnur.org/biblioteca/pdf/2551.pdf, consultado el 31 de agosto de 2017.

92 Human Rights Watch, Puertas cerradas..., cit., p. 74.

93 Boulton, Michael, "Living in a World of Violence: An Introduction to the Gang Phenomenon", Legal and Protection Policy Research Series, Ginebra, ACNUR, 2011, p. 24; Corsetti, Jeffrey D., "Marked for Death: The Maras of Central America and Those Who Flee Their Wrath", Georgetown Immigration Law Fournal, vol. 20, 2006, pp. 407 y 410.

94 ACNUR, Nota de orientación sobre las solicitudes de la condición de refugiado relacionadas con las víctimas de pandillas organizadas, marzo de 2010, párr. 53, disponible en: http://wrwre. refworld.org/cgi- bin/texis/vtx/rwmain/opendocpdf.pdf?reldoc =y $\mathcal{E}^{2} d o c i d=4 b f 4 e 1522$ (fecha de consulta: 31 de agosto de 2017).

95 De acuerdo con la Ley General de los Derechos de Niñas, Niños y Adolescentes, todos los niños menores de 18 años tienen derecho a asistencia legal, pero no gratuita, y

Esta obra está bajo una Licencia Creative Commons

Atribución-NoComercial-SinDerivar 4.0 Internacional, IIJ-UNAM.

Boletín Mexicano de Derecho Comparado, núm. 152, pp. 707-739. 
rellenar sus solicitudes y completar el proceso sin asistencia jurídica (o de ningún otro tipo), a menos que tengan la suerte de ser representados por una de las pocas organizaciones no gubernamentales que proveen asistencia jurídica a los solicitantes de asilo o, más raro aún, sus consulados los auxilien en ello. ${ }^{96}$

$\mathrm{Al}$ respecto, el Comité de los Derechos del Niño ha señalado que a los NNA no acompañados se les debe asignar "lo antes posible" un tutor competente, un paso que considera "una garantía procesal importantísima para el respeto del interés superior de los menores no acompañados o separados de su familia". ${ }^{97}$ Cuando el niño solicita asilo o entabla otros procesos o actuaciones administrativas o judiciales, o cuando es el solicitante principal en un proceso de asilo, se le debe nombrar un representante legal. ${ }^{98}$ Este tutor debe ser "un adulto que esté al corriente de los antecedentes del niño y que sea competente y capaz para representar a éste o a sus intereses superiores". ${ }^{99}$ En los casos en los que se requiera un representante jurídico, el acceso a éste debe ser gratuito. ${ }^{100}$ De manera parecida, las Directrices generales inter-agénciales sobre niñas y niños no acompañados y separados instan "el nombramiento de un representante legal asî como un tutor que promueva una decisión basada en el interés superior del niño o la niña". ${ }^{101}$ Claramente, nada de esto se cumple en México.

a comunicarse libremente con sus abogados. Artículo 92, fr. VII, Ley General de los Derechos de Niñas, Niños y Adolescentes. Este artículo no especifica que los NNA tengan derecho a asistencia legal gratuita, a diferencia de que sí establece su derecho a ser asistidos gratuitamente por un traductor y/o intérprete (artículo 92, fr. V). También véase Ceriani Cernadas, Pablo, (ed.), Niñez detenida, México, Argentina, Fontamara, 2012, p. 16.

96 Human Rights Watch, Puertas cerradas..., cit., pp. 78, 80 y 81.

97 Comité de los Derechos del Nino, Trato de los menores no acompañados y separados de su familia fuera de su país de origen, Observación General núm. 6, GRC/GC/2005/6, 1o. de septiembre de 2005, párr. 21.

98 Ibidem, párr. 21, 33, 34, 36; ACNUR, Directrices sobre la detención: directrices sobre los criterios y estándares aplicables a la detención de solicitantes de asilo y las alternativas a la detención, Ginebra, ACNUR, 2012, párr. 56; Directrices sobre solicitudes de asilo de niños..., cit., párr. 69.

99 Comité de los Derechos del Nino, Observación General núm. 6..., cit., párr. 69.

100 Idem.

101 Comité Internacional de la Cruz Roja, Directrices Generales inter-agenciales sobre niñas y niños no acompañados y separados, Ginebra, ICRC, 2004, p. 34.

Esta obra está bajo una Licencia Creative Commons Atribución-NoComercial-SinDerivar 4.0 Internacional, IIJ-UNAM. Boletín Mexicano de Derecho Comparado, núm. 152, pp. 707-739. 


\section{B. No se garantiza el interés superior del niño en el procedimiento de determinación de refugiado}

En México, es común que la entrevista para determinar si se otorga o no la calidad de refugiado (se trate de NNA o de adultos) se realice por teléfono. Esto se explica, en buena medida, por la limitada capacidad operativa y financiera de la Comar, la cual sólo tiene cuatro delegaciones a nivel nacional para evaluar las solicitudes de asilo. Sin embargo, esto es violatorio del interés superior del niño. Un ejemplo: en 2012 la GNDH hizo una observación a la Comar por no evaluar correctamente la solicitud de asilo de un joven hondureño de 17 años, detenido y no acompañado. Entre otras cosas, la CNDH aseguró que la Comar había llevado a cabo la determinación del caso de condición de refugiado únicamente vía telefónica, en lugar de mediante una entrevista en persona, y había emitido la resolución de la solicitud mientras el niño permanecía detenido en una estación migratoria. En suma, la Comar no llevó a cabo una evaluación adecuada del interés superior del adolescente en cuestión. ${ }^{102}$

$\mathrm{Al}$ respecto, el Comité de los Derechos del Niño ha señalado en el caso de que los NNA estén involucrados en procedimientos administrativos o judiciales, todas las evaluaciones "deben efectuarse en un ambiente de amistad y seguridad y a cargo de profesionales competentes formados en técnicas de entrevistas que tengan en cuenta la edad y el género". ${ }^{103}$ Las evaluaciones iniciales deben recoger: las razones por las que el niño está separado de su familia o no acompañado; una "evaluación de aspectos particulares de vulnerabilidad, en especial relativos a la salud, y de índole física, psicosocial y material, y de otras necesidades de protección como las derivadas de la violencia en el hogar, la trata o el trauma; toda la información de que se disponga para determinar la posible existencia de necesidades de protección internacional". ${ }^{104}$ En sentido similar, la Convención sobre los Derechos del Niño dispone que los NNA tienen el derecho de ser escuchados en todo procedimiento judicial o administrativo que les

102 GNDH, Recomendación núm. 77/2012, Caso del Nino de Nacionalidad Hondureña a quien se negó refugio, 30 de noviembre de 2012, disponible en: http://wrere.cndh.org.mx/sites/all/doc/ Recomendaciones/2012/Rec_2012_077.pdf(fecha de consulta: 31 de agosto de 2017).

103 Comité de los Derechos del Nino, Observación General núm. 6..., cit., párr. 20.

104 Ibidem, párr. 31, inc. iii.

Esta obra está bajo una Licencia Creative Commons

Atribución-NoComercial-SinDerivar 4.0 Internacional, IIJ-UNAM.

Boletín Mexicano de Derecho Comparado, núm. 152, pp. 707-739. 
afecte, ${ }^{105}$ así como de expresar sus opiniones. ${ }^{106}$ Esto requeriría, sin embargo, que los NNA dispongan de toda la información pertinente acerca de, por ejemplo, sus derechos, servicios existentes, en especial en medios de comunicación, el procedimiento para solicitar asilo, la localización de su familia y la situación en su país de origen. ${ }^{107}$ Todo esto en aras de proteger su interés superior.

En México, la Constitución establece que el principio del interés superior del niño quedará reflejado "en todas las decisiones y acciones emprendidas por el Estado", ${ }^{108}$ y la legislación del país requiere que las decisiones tomadas en los procesos de inmigración que involucren a niños reflejen su interés superior. ${ }^{109}$ Pero, como se ha visto, el procedimiento de determinación de refugiado que se sigue en México dista mucho de respetar los estándares de respeto del interés superior del niño: las entrevistas para determinar si se concede asilo a NNA son, muchas veces, por teléfono; no se asignan representantes legales gratuitos a NNA; los NNA permanecen en detención durante el procedimiento; los primeros contactos de los niños son agentes de migración, no sensibilizados en temas de infancia y género; entre otros.

\section{Detención durante el procedimiento de determinación de la calidad de refugiado}

En México, todos los migrantes que no pueden probar que se encuentran en situación migratoria regular son aprehendidos y llevados a una estación migratoria, lo que implica que quedan en detención hasta que puedan regularizar su situación o hasta que sean deportados a su país de

\footnotetext{
105 Artículo 12, fr. 2, Convención sobre los Derechos del Niño.

106 Artículo 12, fr. 1, Convención sobre los Derechos del Niño.

107 Comité de los Derechos del Nino, Observación General núm. 6..., cit., párr. 25.

108 Artículo 4o., GPEUM.
}

109 Artículo 11, Ley de Migración; artículos 5o., fr. III, 9o. y 20, Ley sobre refugiados; artículos 92, fr. IX, 93 y 97, Ley general de derechos de NNA; artículos 35-36, Reglamento de la Ley de Refugiados, y artículos 169, fr. I, 172, 173, 175 y 177, Reglamento de la Ley de Migración. Véase también: SCJN, Menores de dieciocho años: El análisis de una regulación respecto de ellos debe hacerse atendido al interés superior y a la prioridad de la infancia, tesis núm. XLV/2008, 12 de mayo de 2008, disponible en: https://wrwre.scjn.gob.mx/pleno/SecretariaGeneralDeAcuerdos 1/TesisAisladasdelPleno/2008/TA45-2008.pdf(fecha de consulta: 31 de agosto de 2017). 
origen. ${ }^{110}$ La Ley de Migración especifica que la detención es necesaria para el "orden público", ${ }^{111}$ y establece que las órdenes de detención "se expedirán" cada vez que el INM identifique a un migrante que haya entrado de manera irregular en México. ${ }^{12}$ La Ley de Migración permite que los migrantes sean detenidos durante 15 días hábiles, a pesar de que ese período se puede extender a 60 días si hay dificultades prácticas para obtener los documentos de viaje o en la preparación de la repatriación de la persona. No hay límite a la detención si un migrante solicita una revisión administrativa o judicial. ${ }^{113}$

De este modo, de acuerdo con lo dispuesto por la Ley de Migración, al momento en que las autoridades mexicanas entran en contacto con un migrante irregular, sea NNA o adulto, con necesidad de protección internacional o no, la detención es la regla. En principio, los NNA no acompañados y separados deberían ser remitidos a los sistemas del DIF de los estados y de la Ciudad de México en lugar de ser retenidos en las estaciones migratorias. ${ }^{114}$ Sin embargo, la Ley de Migración y sus reglamentos permiten que los NNA no acompañados y separados permanezcan detenidos en las estaciones migratorias "en circunstancias excepcionales", lo cual, en la práctica, es la regla y no la excepción. ${ }^{115}$

\section{Falta de recursos efectivos de revisión}

No hay un recurso de revisión efectivo en caso de negación de la calidad de refugiado, lo cual propicia, en última instancia, que se viole el derecho a la vida del NNA solicitante de asilo, por ejemplo, si es devuelto a un lugar donde corre peligro su vida y realmente calificaba para obte-

\footnotetext{
110 Artículo 3o., fr. XX, Ley de Migración.

111 Artículo 99, Ley de Migración.

112 Artículos 100 y 144, Ley de Migración.

113 Artículo 111, Ley de Migración.

114 Artículo 112, fr. I, Ley de Migración; artículo 175, Reglamento de Ley de Migración; artículo 89, Ley General de los Derechos de Niñas, Niños y Adolescentes.

115 Artículo 176, Reglamento de Ley de Migración. En este sentido, véase lo que señala Rojas, Christian, Informe alternativo sobre el cumplimiento de México de la Convención Internacional sobre la Protección de los Derechos de Todos los Trabajadores Migratorios y de sus Familiares para el Comité de los Trabajadores Migratorios y de sus Familiares de Naciones Unidas (CMW), 2017, pp. 20 y ss.
}

Esta obra está bajo una Licencia Creative Commons

Atribución-NoComercial-SinDerivar 4.0 Internacional, IIJ-UNAM.

Boletín Mexicano de Derecho Comparado, núm. 152, pp. 707-739. 
ner la calidad de refugiado en México. Lo anterior en virtud de que la misma autoridad que decidió negar la condición de refugiado - la Comar- es quien revisa la legalidad de su propia decisión: es juez y parte en el mismo proceso. ${ }^{116}$ Aún más, en caso de que la persona solicitante de asilo rechazada impugne en segunda instancia la revisión administrativa de la Comar, la ley de la materia dispone que el tribunal facultado para conocer el asunto es el Tribunal Federal de Justicia Administrativa (TFJA), ${ }^{117}$ lo cual puede presentar, al menos, tres problemas (si bien la experiencia de los últimos años muestra una loable función de los integrantes del TFJA):

1. El TFJA es un tribunal administrativo, experto en materia administrativa (y fiscal); es decir, no está especializado en temas migratorios o de asilo.

2. El TFJA se encuentra sujeto irrestrictamente al principio de legalidad y, en consecuencia, está imposibilitado de realizar una labor interpretativa (propia de los jueces) a favor de las personas solicitantes de asilo y de acuerdo con las particularidades del caso, que pueden ser, literalmente, de vida o de muerte.

3. El TFJA no es completamente independiente en el ejercicio de sus funciones, ya que está adscrito a la administración pública. De nueva cuenta, tenemos un conflicto de intereses: el mismo poder público, el Poder Ejecutivo, resulta ser juez y parte en el mismo proceso. Con esto se viola, en última instancia, el principio de división de poderes, sobre el cual descansa el Estado democrático

116 Artículo 25, Ley sobre Refugiados, Protección Complementaria y Asilo Político; Artículo 59, Reglamento de la Ley sobre Refugiados y Protección Complementaria, que señala: "En contra de la negativa de reconocimiento de la condición de refugiado, de la cesación, de la cancelación, de la revocación o del retiro de la protección complementaria, de la negativa de autorización de reunificación familiar, así como del dictamen sobre la protección efectiva a que se refiere el artículo 91 de este Reglamento, procede el recurso de revisión”. Y el Artículo 86 de la Ley Federal de Procedimiento Administrativo dispone: "El escrito de interposición del recurso de revisión deberá presentarse ante la autoridad que emitió el acto impugnado y será resuelto por el superior jerárquico, salvo que el acto impugnado provenga del titular de una dependencia, en cuyo caso será resuelto por el mismo".

117 Artículo 83, Ley Federal de Procedimiento Administrativo; artículo 3o., fr. XII, Ley Orgánica del Tribunal Federal de Justicia Fiscal y Administrativa.

Esta obra está bajo una Licencia Creative Commons Atribución-NoComercial-SinDerivar 4.0 Internacional, IIJ-UNAM. Boletín Mexicano de Derecho Comparado, núm. 152, pp. 707-739. 
de derecho y que funge como freno a los abusos de poder de los poderes públicos. ${ }^{118}$

Es preciso admitir que la presentación y el análisis de estos obstáculos resulta, aún, grosa y preliminar. Como he adelantado, la investigación sobre el tema resulta aún insuficiente. Por esta razón, esta tipología debe ser entendida como una primera aproximación, aunque una que, sin duda, resulta fundamental en el contexto actual.

\section{REFLEXIONES FINALES}

Este artículo ha tenido como objetivos principales, por un lado, sistematizar y hacer visibles las reglas de procedimiento que tienen que seguir los NNA para solicitar y recibir asilo en México y, en su caso, para interponer el recurso de revisión de la decisión administrativa que lo negó. Y, por el otro, identificar y analizar los obstáculos más notorios del propio marco legal y su práctica cotidiana, presentes en el desarrollo del proceso. Esto con el fin de dilucidar, desde una perspectiva crítica, la situación real del derecho al asilo de los NNA en México y, a su vez, construir una base para que investigaciones futuras puedan proponer rutas legales que solventen tales limitaciones.

Como se adelantó en la introducción, los objetivos anteriores hacen visible el proceso para obtener la calidad de refugiado en México en su especificidad y sus consecuencias. Como he intentado mostrar, el proceso, en sí, resulta opaco, incluso para el lector especializado. Esta opacidad resulta, en gran medida, del marco jurídico y su aplicación por el aparato burocrático del Estado. Sin embargo, surge también de un amplio conjunto de prácticas cotidianas que dificultan a las personas solicitantes de asilo el acceso a dicho procedimiento, sean NNA o adultos. Esta situación genera consecuencias más graves en el caso de los NNA, por su particular estado de vulnerabilidad, dejándolos en estado de indefensión respecto al

118 Véase, por ejemplo, el freno que el Poder Judicial ha puesto a los abusos de poder del Presidente Donald J. Trump de los Estados Unidos y sus órdenes ejecutivas en materia de refugio: Shear, Michael D. et al., "Judge Blocks Trump Order on Refugees Amid Chaos and Outcry Worldwide", The New York Times, 28 de enero de 2017, disponible en: https:// wrwenytimes.com/2017/01/28/us/refugees-detained-at-us-airports-prompting-legal-challenges-totrumps-immigration-order.html?_r=0 (fecha de consulta: 31 de agosto de 2017).

Esta obra está bajo una Licencia Creative Commons

Atribución-NoComercial-SinDerivar 4.0 Internacional, IIJ-UNAM.

Boletín Mexicano de Derecho Comparado, núm. 152, pp. 707-739. 
procedimiento de determinación de refugiado al que se enfrentan, con el fin de no ser devueltos al país de origen que los ha "expulsado", poniendo, con ello, en riesgo su seguridad y, a menudo, su vida.

$\mathrm{El}$ análisis anterior permite establecer que existe, al menos, una correlación fuerte entre las normas que regulan el proceso de determinación de la calidad de refugiado en México, los diversos obstáculos que se manifiestan al momento en que los NNA deciden entablarlo y las violaciones a los derechos humanos, tan comunes en el caso de los NNA que buscan asilo en nuestro país. Por tanto, a mi parecer, el asunto medular a discutir es la "substanciación" del procedimiento para recibir asilo, es decir, la relación entre derecho (como conjunto de normas), los procedimientos legales (como praxis gubernamental) y la vida (real y cotidiana) de los sujetos que habitan los espacios definidos mediante procesos como el descrito. En otras palabras, al sugerir, como hago en la introducción, que el derecho al asilo en México queda vacío, hablo de un problema de substanciación, de derecho vuelto praxis cotidiana. Esto es: la dimensión jurídica, dada por el entramado de normas y procedimientos que dan forma al proceso de determinación de la calidad de refugiado, tiene efectos concretos sobre una dimensión estrictamente práctica, caracterizada, en el agregado, por la violación sistemática y normalizada de los derechos humanos, entre éstos: el debido proceso, el respeto al interés superior del niño, el acceso a la justicia, la igualdad ante la ley y, en última instancia, el derecho a la vida. Las consecuencias del andamiaje jurídico formal del derecho al asilo en México, reitero, resultan particularmente graves en la práctica, pues impactan, a menudo de forma funesta, la vida de los NNA que lo solicitan. Dada la opacidad del procedimiento entero - en especial para los NNA involucrados, pero, también, con respecto a la mirada pública- se puede hablar del proceso legal de determinación de la calidad de refugiado, en su estado actual, como determinante de los linderos jurídicos de un espacio de excepción.

De este modo, enfrentamos un problema grave de substanciación: un proceso legal viciado y opaco que produce un derecho humano al asilo sin contenido, sistemáticamente no realizable para las personas con necesidades de protección internacional. El análisis en este artículo permite concluir que México ha creado, a través del marco jurídico que regula el proceso de determinación de la calidad de refugiado, un estado de excepcionalidad permanente para las personas solicitantes de asilo, que las deja 
en un limbo jurídico y en total indefensión. En este sentido, las palabras del alto comisionado de los Derechos Humanos de la ONU describen particularmente bien el caso de estos NNA: quedan emplazados entre la amenaza constante de perder la vida — si regresan a casa- - y una barrera casi infranqueable, construida con normas, decisiones y procedimientos opacos, dada la forma específica del proceso jurídico para pedir asilo en México.

Hoy la amenaza de un muro de Trump, violatorio y xenófobo causa justa indignación. Sin embargo, hoy también es momento de que nos atrevamos a mirar críticamente aquellos muros de factura nacional que nos separan del respeto cabal a los derechos humanos, al que México está legal y éticamente obligado.

\section{BIBLIOGRAFÍA}

AGNUR, Directrices sobre la detención: directrices sobre los criterios y estándares aplicables a la detención de solicitantes de asilo y las alternativas a la detención, Ginebra, ACNUR, 2012.

AGNUR, Directrices sobre protección internacional: solicitudes de asilo de niños bajo los artículos 1(A)2 y 1(F) de la Convención de 1951 y / el Protocolo de 1967 sobre el Estatuto de los Refugiados ("Directrices sobre solicitudes de asilo de niños"), UN Doc. HCR/GIP/09/08, 22 de noviembre de 2009.

ACNUR, Directrices sobre Protección Internacional núm. 4: La "alternativa de huida interna o reubicación" en el contexto del artículo 1A (2) de la Convención de 1951 o el Protocolo de 1967 sobre el Estatuto de los Refugiados, HCR/GIP/03/04, 23 de julio de 2003.

ACNUR, Niños en fuga, Washington D. C., ACNUR, 2014.

ACNUR, Nota de orientación sobre las solicitudes de la condición de refugiado relacionadas con las víctimas de pandillas organizadas, marzo de 2010.

Agamben, Giorgio, Estado de excepción. Homo sacer II, I, trad. de Flavia Costa e Ivana Costa, Buenos Aires, 2004.

Bauman, Zygmunt, Archipiélago de excepciones, Buenos Aires, Katz, 2008.

Boulton, Michael, "Living in a World of Violence: An Introduction to the Gang Phenomenon", Legal and Protection Policy Research Series, Ginebra, ACNUR, 2011. 
Centro de Derechos Humanos Fray Matías de Córdova, “Tapachula, Chiapas: La experiencia de detención en la frontera sur mexicana”, en BARJA CORIA, Joselin, Derechos cautivos. La situación de las personas migrantes y sujetas a protección internacional en los centros de detención migratoria: Siete experiencias de monitoreo desde la sociedad civil, México, Frontera con Justicia, 2015.

Ceriani Cernadas, Pablo, (ed.), Niñez detenida, México, Argentina, Fontamara, 2012.

GNDH, Informe sobre la problemática de niñas, niños y adolescentes centroamericanos en contexto de migración internacional no acompañados en su tránsito por México, y con necesidades de protección internacional, México, 2016.

GNDH, Recomendación núm. 77/2012, Caso del Niño de Nacionalidad Hondureña a quien se negó refugio, 30 de noviembre de 2012.

Comisión Interamericana de Derechos Humanos, Derechos humanos de los migrantes y otras personas en el contexto de la movilidad humana en México, Washington D. C., CIDH, 2013.

Comité de los Derechos Del NiÑo, Trato de los menores no acompañados y separados de su familia fuera de su país de origen, Observación General núm. 6, GRC/GC/2005/6, 1 de septiembre de 2005.

Comité Internacional de la Gruz Roja, Directrices Generales Inter-Agenciales sobre Niñas y Niños No Acompañados y Separados, Ginebra, ICRC, 2004.

CorsetTi, Jeffrey D., "Marked for Death: The Maras of Central America and Those Who Flee Their Wrath", Georgetown Immigration Law Journal, vol. 20, 2006.

FRANCO, Leonardo (coord.), El asilo y la protección internacional de los refugiados en América Latina, Buenos Aires, Siglo XXI, 2003.

Georgetown Law Human Rights Institute, The Cost of Stemming the Tide: How Immigration Enforcement Practices in Southern Mexico Limit Migrant Children's Access to International Protection, Washington DC, Georgetown University, 2015.

Gil-Bazo, María Teresa y NogueIRA, María Beatriz B., "El asilo en la práctica de los Estados de América Latina y África", Nuevos temas en la investigación sobre refugiados, Informe de investigación 249, ACNUR, 2013.

Human Rights Watch, Puertas cerradas. El fracaso de México a la hora de proteger a niños refugiados y migrantes de América Central, EUA, HRW, 2016. 
I(DH)Eas, Litigio Estratégico en Derechos Humanos, En tierra de nadie: El laberinto de la impunidad: Violaciones de los derechos humanos de las personas migrantes en la región del Soconusco, México, 2011.

Instituto Para la Seguridad y la Democracia, Diagnóstico del Instituto Nacional de Migración: hacia un sistema de rendición de cuentas en pro de los derechos humanos de las personas migrantes en México, México, Insyde, 2013.

KNIPPEN, Jose et al., Un camino incierto: Fusticia para delitos y violaciones a los derechos humanos contra personas migrantes y refugiadas en México, México, Fundar, Casa del Migrante de Saltillo "Frontera con Justicia", 2015.

LANDA LANDA, María Guadalupe et al., "El legado científico del exilio español en México a través de Ciencia", Revista Hispanoamericana de Ciencias Puras y Aplicadas, 2009.

LOCHAK, Danièle, Face aux migrants: état de droit ou état de siège?, París, Textuel, 2007.

Médicos sin Fronteras, Forzados a huir del Triángulo Norte de Centroamérica: una crisis humanitaria olvidada, Ciudad de México/ Nueva York/ Río de Janeiro/ Barcelona, MSF, 2017.

Musalo, Karen et al., Niñez y migración en Centro y Norte América: causas, políticas, prácticas y desafios, San Francisco y Buenos Aires, Center for Gender and Refugee Studies, UC Hastings, y Universidad Nacional de Lanús, 2015.

Nebehay, Stephanie, "Few new pledges at U.N. talks to resettle Syrian refugees", Reuters, 30 de marzo de 2016.

PLA, Dolores y Vázquez, Álvaro, El exilio español en la Ciudad de México, México, Turner, 2011.

Sassen, S., Expulsions. Brutality and Complexity in the Global Economy, Cambridge, Harvard University Press, 2014.

RoJAS, Christian, Informe alternativo sobre el cumplimiento de México de la Convención Internacional sobre la Protección de los derechos de todos los trabajadores Migratorios y de sus Familiares para el Comité de los Trabajadores Migratorios y de sus Familiares de Naciones Unidas (CMW), 2017.

SCJN, Menores de dieciocho años: el análisis de una regulación respecto de ellos debe hacerse atendido al interés superior y a la prioridad de la infancia, tesis núm. XLV/2008, 12 de mayo de 2008.

Segob, Unidad de Política Migratoria, Boletín Mensual de Estadísticas Migratorias 2016, México, 2016.

Esta obra está bajo una Licencia Creative Commons

Atribución-NoComercial-SinDerivar 4.0 Internacional, IIJ-UNAM.

Boletín Mexicano de Derecho Comparado, núm. 152, pp. 707-739. 
Serrano Migallón, Fernando, El asilo politico en México, México, Porrúa, 1998.

SHEAR, Michael D. et al., "Judge Blocks Trump Order on Refugees Amid Chaos and Outcry Worldwide", The New York Times, 28 de enero de 2017.

Sin Fronteras IAP, Evolución y retos del asilo en México. 20 años de asistencia legal e incidencia por las personas refugiadas, México, Sin Fronteras, 2016.

Sin Fronteras IAP, La ruta del encierro, México, Sin Fronteras IAP, 2014.

UIA, CDHFMC, La interpretación y aplicación del derecho internacional y nacional de los refugiados. Análisis de las resoluciones de primera instancia de la Comisión Mexicana de Ayuda a Refugiados, México, UIA, CDHFMC, 2017.

UReste, Manu, "México recibe 67\% más solicitudes de refugio, pero sólo tiene 15 oficiales para atender 2 mil casos", Animal Político, 19 de junio de 2015. 